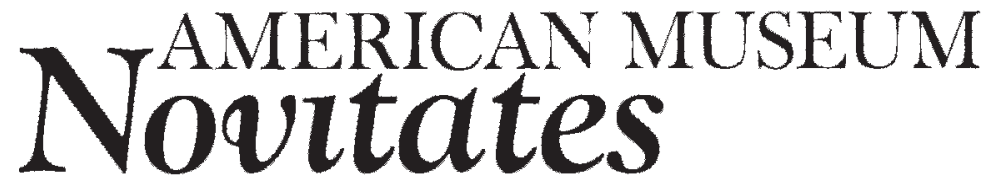

PUBLISHED BY THE AMERICAN MUSEUM OF NATURAL HISTORY CENTRAL PARK WEST AT 79TH STREET, NEW YORK, NY 10024 Number 3644, 24 pp., 43 figures

March 31, 2009

\title{
Hospicidal Behavior of the Cleptoparasitic Wasp Sapyga luteomaculata And Investigation into Ontogenetic Changes in Its Larval Anatomy (Hymenoptera: Vespoidea: Sapygidae)
}

\author{
JEROME G. ROZEN, JR., ${ }^{1}$ AND SOLIMAN M. KAMEL ${ }^{2}$
}

\begin{abstract}
This study describes the nesting biology of the Egyptian cleptoparasitic wasp Sapyga luteomaculata Pic, which attacks the nests of two species of bees, Osmia submicans Morawitz and Megachile minutissima Radoszkowski, both belonging to the Megachilidae. We include descriptions of the egg/mature oocyte and of the first and last larval instars. We also identify the anatomical changes in the larva that take place as it transforms through intermediate instars from a host-killing first instar to a form adapted to feeding on the stored provisions supplied by the host. Biological subjects treated are egg deposition, ovariole statistics, eclosion, larval behavior including cocoon construction and defecation, and competition with other cleptoparasites. Comparisons are made throughout with accounts of other Sapyginae. Many biological and larval anatomical similarities between Sapyga and cleptoparasitic bees are recognized, and only a few possible cleptoparasitic novelties are identified.
\end{abstract}

\section{INTRODUCTION}

While studying the biology of Coelioxys (Allocoelioxys) coturnix Pérez, a cleptoparasitic bee that attacks nests of Megachile (Eutricharaea) minutissima Radoszkowski, we discovered females of the wasp Sapyga luteomaculata Pic parasitizing nests of the same host and also of Osmia (Pyrosmia) submicans Morawitz. During the course of the investigation, we recovered immature stages of this Sapyga from nests of both

\footnotetext{
1 American Museum of Natural History (rozen@amnh.org).

2 Professor, Department of Plant Protection, Faculty of Agriculture, Suez Canal University, Ismailia, Egypt (soliman_90@hotmail.com).
} 
hosts $^{3}$ and made observations on its hospicidal behavior. We present here our understanding of the mode of cleptoparasitism of this species and other information concerning its natural history and, while doing so, compare this species with literature accounts of other Sapygidae. We also provide our analysis of the anatomy of its first and last larval instars and of the anatomical and behavioral changes that take place from one instar to the next. Throughout we compare the anatomical and behavioral similarities and differences between Sapyga luteomaculata and cleptoparasitic bees, which clearly show a strong evolutionary convergence.

Although there are a number of literature references identifying hosts of Sapyga (e.g., Krombein et al., 1979), the most complete investigation of its biology and immature stages to date was presented by Torchio (1972a, 1972b, 1979), pertaining to S. pumila Cresson. The reader is referred to those works for another understanding of the biology of an example of the genus. Malyshev (1968) also gave some biological information pertaining to Sapyga similis Fabricius. Although we were unable to obtain the work of Brechtel (1986), Westrich (1989) recounted much of the information in it, with reference to $S$. clavicornis (Linnaeus) and Sapygina decemguttata (Jurine). The biologies of several species of Polochrum (Sapygidae) were offered by Hurd and Moure (1961; see references therein), Parker (1926), who also described the egg and the first and last instars of $P$. repandum Spinola, and Grandi (1962), who treated and illustrated the mature larva of the same species.

Although we first detected the presence of Sapyga luteomaculata in September 2006, our field investigation into its biology was initiated in 2007 from April 24 to May 12, primarily on the campus of Suez Canal University, Ismailia, Egypt $\left(\mathrm{N} 30^{\circ} 37^{\prime} 10^{\prime \prime}\right.$ E32 $\left.2^{\circ} 15^{\prime} 58^{\prime \prime}\right)$, where the second author (S.M.K.) has been

\footnotetext{
${ }^{3} \mathrm{We}$ also recovered a single last instar of Sapyga luteomaculata from a nest of an unknown megachilid at the Ismailia Experiment Station on May 12, 2008, that lines its cells only with pollen moistened with nectar. This seems to be evidence that host specificity of Sapyga is a function of nesting ecology rather than the cleptoparasitic female's ability or need to identify the taxonomic affiliation of the host
}

developing a program to rear Megachile minutissima and other possible pollinators of alfalfa. The stock for the rearing program came from several villages near Tel el-Kebir $\left(\mathrm{N} 30^{\circ} 33^{\prime} 30^{\prime \prime} \mathrm{E} 31^{\circ} 56^{\prime} 13^{\prime \prime}\right)$, about $50 \mathrm{~km}$ west of Ismailia, also on the Nile Delta. No doubt the two cleptoparasitic species were introduced with the importation of the hosts' nests to the university campus. Because of the large array of artificial nesting panels (trap nests) established by S.M.K., we were able to gather considerable study material for this investigation as well as for our study of Coelioxys coturnix (Rozen and Kamel, 2008).

Although most of our specimens and observations were from the trap nests on the university campus, we also collected nest samples from some of the panels deployed in the field at Tel el-Kebir, where parasitized nests of Osmia submicans were recovered. Still other nests were collected from panels posted at the Ismailia Experimental Station, Agricultural Research Center, Ismailia. Because this locality is only a few kilometers from the university, observations from there are not differentiated from those at the university.

\section{MATERIALS, METHODS, AND TERMINOLOGY}

Nest panels are oversized trap nests designed to attract and rear large numbers of cavity-nesting bees (Rozen and Kamel, 2008: figs. 1, 2). Although varying somewhat in outside dimensions, a typical nesting panel is built from a series of polystyrene boards (approximately $90 \mathrm{~cm} \times 15 \mathrm{~cm} \times 1.8 \mathrm{~cm}$ ), each of which has a series of channels $12 \mathrm{~cm}$ long (shorter than the width of polystyrene board) spaced $15 \mathrm{~mm}$ apart on center, cut into the upper and lower board edges on one side of the board so that when boards are stackedin succession, two channels of opposing boards when properly aligned form receptacles for the nest straws (Rozen and Kamel, 2008: fig. 2). The straws, about $12 \mathrm{~cm}$ long, with a $5.1 \mathrm{~mm}$ inside diameter, are constructed from rolled paper and provide the preformed cavity in which the host bees can build nests. Panels when fully constructed are framed to hold the polystyrene boards together and mounted on a firm piece of 
plywood, which is then hung vertically either near the alfalfa field at Suez Canal University or at appropriate sites near clover (Trifolium alexandrinum L.) or alfalfa (Medicago sativa L.) fields in the vicinity of Tel el-Kebir, so that the straws become horizontal. See Rozen and Kamel (2008: figs. 1-3) for images. The trap nests are described elsewhere in greater detail (http://www.polinatorparadise.com/Egypt.htm).

Most straws that we examined had been used in one or more previous seasons and thus often contained remnants of nests and/or cocoons of preceding generations of Megachile minutissima, other Megachile, one or more species of Osmia, Sapyga luteomaculata, Stelis (Stelis) murina Pérez, and Coelioxys coturnix. The most abundant nester in the panels on campus, $M$. minutissima, apparently never removed accumulated debris from previous generations but merely mined through the cocoons and leaf litter, selecting a space and installing fresh leaf snippets to construct a new cell within the existing materials. Rarely were more than two freshly provisioned cells found end-to-end, generally toward the rear end of a straw. With straws not used previously, cells were almost invariably found only at the far rear end. Entrances to straws containing fresh cells were closed with leaf snippets loosely packed against one another within the first several $\mathrm{cm}$ of the front end, and the passage between the stopper and the fresh and old cells was left open. It is not surprising that Dermestidae often occupied nest straws, where they fed on the dead bodies of failed immature or adult bees and other debris, although live immature bees there appeared unharmed for the most part by these scavengers.

To study the nests, we simply pulled individual straws from the polystyrene panel with forceps or pliers and inserted them in an improvised carrying container made from pieces of polystyrene bound together by strapping tape, so that horizontal orientation of the straws could be maintained during transport. In the lab, each straw was cut lengthwise with a utility knife, and the two cut edges were spread to reveal the cells, which we then opened with forceps under a stereomicroscope. Specimens were preserved, reared in plastic rearing dishes, or discarded, depending upon their perceived utility.
Where we describe the egg of Sapyga luteomaculata, we also present statistics on the number of ovarioles, egg size, and number of mature oocytes carried by cleptoparasites. This area of investigation was pioneered by Iwata (1965) and Iwata and Sakagami (1966) and added to by a number of more recent studies (e.g., Alexander, 1996; Rozen, 2003). For the study of egg size in bees, Iwata and Sakagami (1966) developed an index of egg size relative to the size of the female bee by dividing the length of the largest mature oocyte or egg by the distance between the outer rims of the female tegulae. An egg index when applied to such a distant relative as a Sapyga, in which the adult anatomy differs markedly from that of a bee, has doubtful value and is not employed here.

The terminology regarding anatomy follows that commonly used in descriptions of bee larvae (Rozen, 2001). It corresponds closely with that employed by Kojima (1998) for social Vespidae, except for the following (Kojima's terms italicized parenthetically): epistomal area (palate); epistomal ridge (or suture) below (or laterad of) anterior tentorial pit (parafrontal suture); epistomal ridge (or suture) between anterior tentorial pits (frontclypeal [sic] suture); postoccipital ridge (posterior thickening of head capsule). All head ridges are internal and are best observed on head capsules that have been cleared of tissue by brief boiling in an aqueous solution of sodium hydroxide or on cast larval exoskeletons (euphemistically termed "skins" hereafter).

\section{BIOLOGICAL INFORMATION}

Host Preference: We first detected the presence of Sapyga luteomaculata in September 2006 when we encountered the heavily sclerotized and pigmented head capsules of dead first instars, often several to a cell, in nests of Osmia submicans. We tentatively concluded on this basis that it was a cleptoparasite of $O$. submicans. When we commenced the investigation on this cleptoparasite in April/May 2007, we were unable to identify active nests of $O$. submicans, although a few females and more males were seen. Apparently too early to catch the main nesting season of Osmia, we realized that adult $S$. 

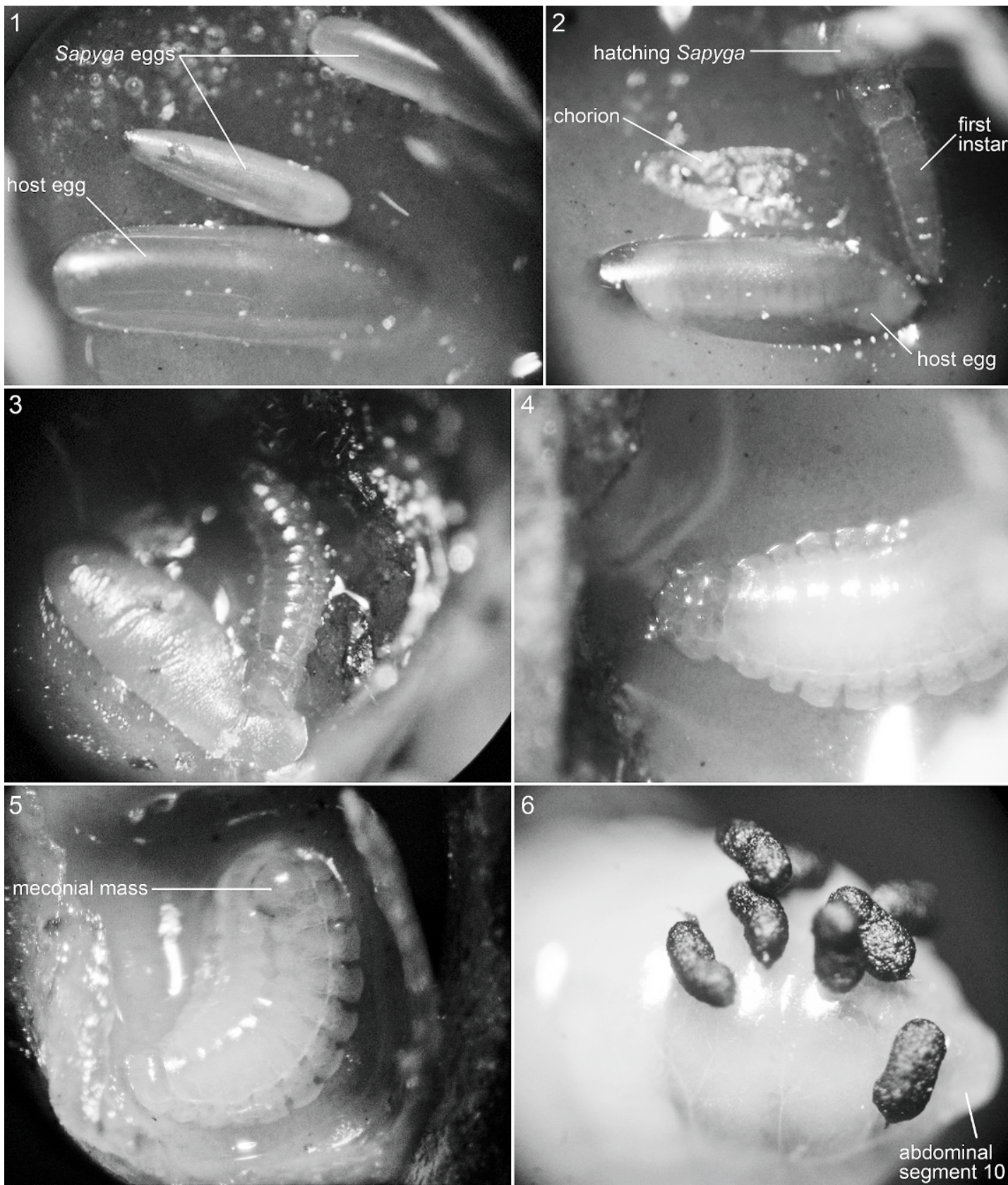

Figs. 1-4. Macrophotographs of live eggs and larvae of Sapyga luteomaculata. 1. Two eggs of cleptoparasite floating on provisions in host cell with host egg at bottom of picture. 2. Same cell as in fig. 1, later, first cleptoparasite egg now hatched leaving chorion behind and first instar attacking other cleptoparasite, which has hatched or is about to hatch; host egg not yet killed. 3. First instar in another cell attacking host egg that is already flaccid. 4. Second instar, showing navicular shape and scalloped lateral outline. 5. Third instar, showing well-defined, opaque yellowish meconial mass at rear of body. 6. Fecal pellets on abdominal apex of feeding fourth instar, showing their shape, darkness in coloration, and, on some, taillike process at apices; note small but projecting apical abdominal segment 10 of actively feeding, defecating larva. 
luteomaculata were moderately abundant around the nest entrances of Megachile minutissima. The discovery of immature stages of $S$. luteomaculata in these nests demonstrated that this cleptoparasite has at least two acceptable hosts, although the preferred host may well be $O$. submicans as judged by the abundance of cleptoparasite cocoons in nests of O. submicans. At Tel el-Kebir, more than a week after commencing our studies of the nest straws on campus, we recovered straws with active nests of $O$. submicans deployed there a week earlier.

On a subsequent visits to the nest panels at Suez Canal University on March 26-April 10, 2008 (about one month earlier in the season than the April/May 2007 study period) and again in May 8-21, 2008, we found abundant Megachile minutissima nesting and many Coelioxys coturnix. No Osmia submicans were nesting in March 26-April 10, and only a few $S$. luteomaculata were observed at that time. We interpret the lack of synchrony of the appearance of $S$. luteomaculata with $M$. minutissima early in the seasons as probable evidence that the adult activity of $S$. luteomaculata is dictated by that of its primary host, O. submicans.

Adult Activity: We often saw females of Sapyga luteomaculata on campus in April/ May 2007 flying in front of the nesting panels, where they commonly alighted either to rest for a short time on the polystyrene surface or to inspect nest entrances. None was observed to enter a nest. We collected a few males skimming the ground below the panels but never saw them flying with females along the surface of the panels. Mating, never observed, may take place when females drop to the ground at the base of the panels or at some distant stations away from the nesting area, as reported for S. pumila (Torchio, 1972a).

ABundance: During the first seven days of our investigation on campus in April/May 2007, we found only seven cells of Megachile minutissima containing eggs/larvae of Sapyga luteomaculata, whereas during the same period we retrieved well over 40 cells invaded by Coelioxys coturnix.

EgG Deposition: In cells of Megachile minutissima containing eggs of Sapyga, all eggs rested lengthwise on the surface of the provisions except in one case, in which, presumably by chance alone, the egg rested partly on the host egg. No cells were observed containing a Sapyga egg without a host egg present. In cells of Osmia submicans from Tel el-Kebir, Sapyga eggs were scattered on the surface of the provisions (fig. 1), on the host egg, and one was attached to the front closure (although its placement there may have accidentally occurred during transport to the lab). These facts suggested that she oviposits through the cell closure as Torchio (1972a) described for S. pumila, or (probably less likely) that the cleptoparasite enters the cell and oviposits while the host female is away gathering cell-closure material, as is the case for Coelioxys coturnix (Rozen and Kamel, 2008). Torchio (in lit., April 28, 2008) on reviewing the manuscript provided strong evidence that only closed cells are parasitized. This evidence comes from his studies on the functioning of the ovipositor, from direct observations on a species other than S. pumila, and from the fact that he never found eggs of $S$. pumila in uncapped cells in "thousands" of examinations. We found that some parasitized cells contained a single egg of $S$. luteomaculata, but a few cells of $M$. minutissima contained two cleptoparasitic eggs (fig. 1). Cells of $O$. submicans held up to three such eggs, although a single egg to a cell seemed the norm.

Egg Description and Ovariole StatisTICs: Eggs (fig. 1) and mature oocytes (fig. 5) of Sapyga luteomaculata are long, 1.96-2.1 mm $(\mathrm{N}=3)$ (those of Coelioxys coturnix have a median length of $1.47 \mathrm{~mm}$ [Rozen and Kamel, 2007]), slender, and slightly curved; they are widest near midlength with their anterior end broadly rounded and taper posteriorly to a narrowly round posterior end. Thus, they tend to be slightly shorter than the eggs/mature oocytes of both hosts, but much thinner $(0.44$ $0.46 \mathrm{~mm}, \mathrm{~N}=3$ ), and their tapering posterior contrasts with the nearly parallel-sided host eggs. Their chorion, though transparent, is thick and apparently rather tough, unlike that of the host egg or that of Coelioxys coturnix, both of which have distinctly thin, fragile chorions. The chorion of $S$. luteomaculata is faintly pigmented. SEM examination of an egg (fig. 8) revealed that it seemed to be covered with a flaking substance, perhaps that which accounts for the 


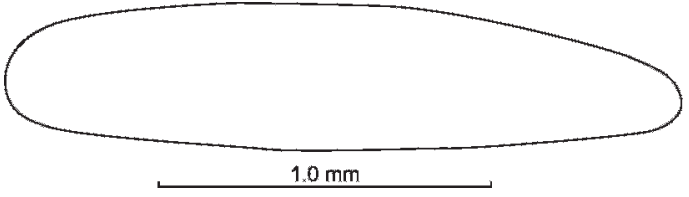

Fig. 7. Diagram of mature oocyte of Sapyga luteomaculata.

sticky surfaces of eggs of $S$. pumila reported by Torchio (1972a). Although the micropyle could be detected only with extreme difficulty (fig. 8) presumably because of this coating, we observed it at the anterior poles of several mature oocytes from a female whose ovaries were dissected in the field and preserved for later dissection of the oocytes just before SEM preparation according to the method described by Rozen (2003) for bees. The micropyle consisted of a tight cluster of 6-7 openings (figs. 9, 10) without other signs of chorionic ornamentation.

The egg of Sapyga luteomaculata, though somewhat larger, closely matched Torchio's (1972a) description and photographs of eggs of $S$. pumila, although he did not examine the micropyle with an SEM. Westrich (1989) refers to the eggs of $S$. decemguttata and $S$. clavicornis as torpedo shaped and pictures the latter; these eggs are slightly smaller than those of $S$. luteomaculata, but the egg of at least $S$. clavicornis appears identical in other respects to that of $S$. luteomaculata. The egg of Polochrum repandum is $2.65 \mathrm{~mm}$ long and slender (Parker, 1926), and thus longer than any of those of Sapyga known so far.

Among cleptoparasitic bees, those that oviposit in cells that are still open and being visited by host females have much smaller eggs than their hosts and thus are afforded two selective advantages: small eggs are more easily secreted from returning host females than large ones, and a female cleptoparasite can accommodate more small mature oocytes than can a bee of the same size with large mature oocytes (Rozen, 2003). Cleptoparasitic bees that introduce eggs into cells that are not inspected by returning host females tend to have larger eggs than cleptoparasitic eggs subjected to discovery by returning hosts (Rozen, 2003). Thus, the large size of the egg of $S$. luteomaculata seems consistent with the former situation if one assumes that, after $M$.
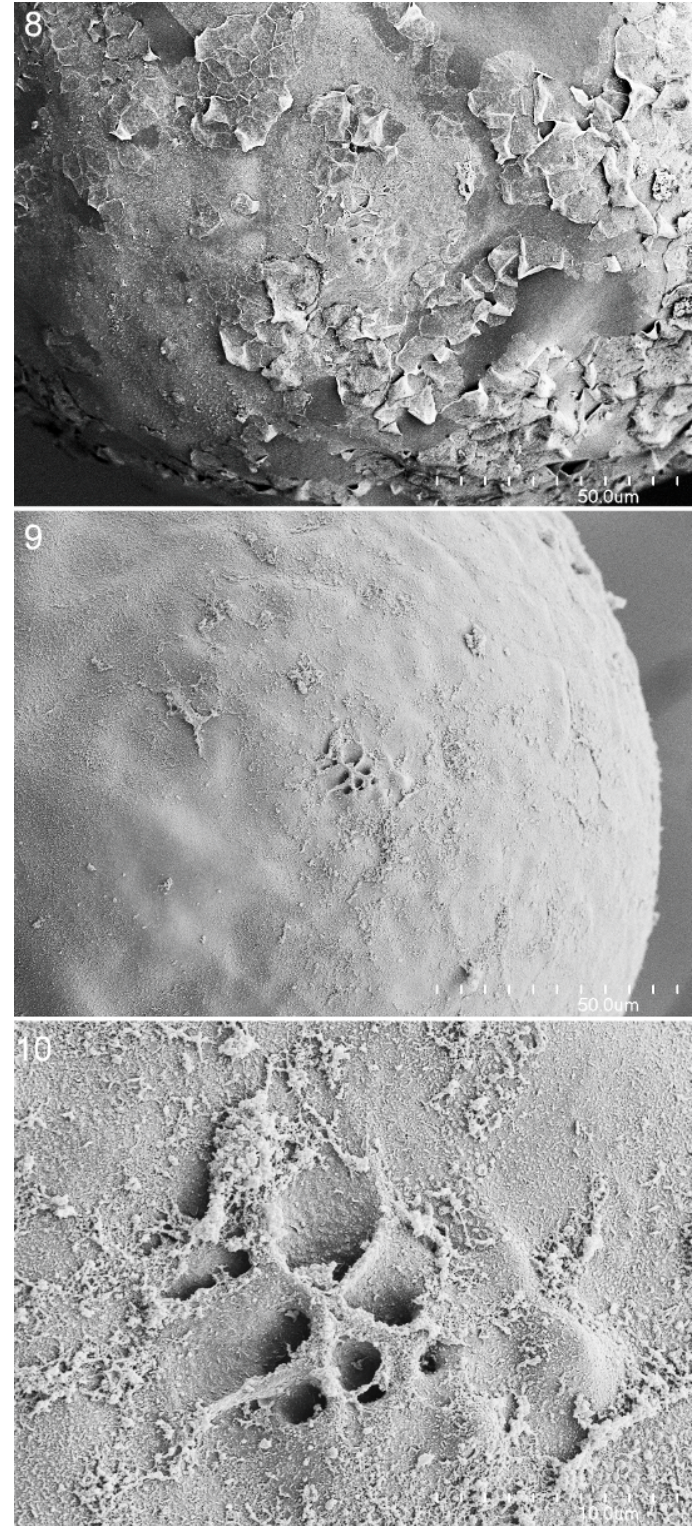

Figs. 8-10. SEM micrographs of egg and mature oocyte of Sapyga luteomaculata. 8. Anterior end of egg showing chorion obscured by flaking coating; micropyle thought to be at center of picture. 9, 10. Anterior end of mature oocyte showing micropyle at anterior pole and close-up of micropyle, respectively.

minutissima deposits her egg, she seals the cell without re-inspecting it. Such is the case with Radoszkowskiana rufiventris (Spinola) (Rozen and Kamel, 2007) and Coelioxys coturnix 
(Rozen and Kamel, 2008). This implies either that the Sapyga female, like those of $R$. rufiventris and C. coturnix, enters the host cell to oviposit after the cell has been fully provisioned and the host egg deposited, presumably while the host female is gathering material for cell closure, or that the female of S. luteomaculata, like that of $S$. pumila, inserts her egg though the cell closure (Torchio, 1972a, in lit., April 28, 2008), which is almost certainly the correct explanation.

Examination of ovaries of four females of Sapyga luteomaculata showed that each had five ovarioles per ovary except one specimen had six ovarioles in one ovary. Such statistics need to be compared with those of close relatives to determine what significance they might have. In solitary bees, the normal number of ovarioles is three per ovary for all known families except the Apidae, in which four ovarioles per ovary is normal. In a few cleptoparasitic groups, most notably in the Nomadinae (Apidae), the number of ovarioles in each ovary is greater, presumably an adaptation for a female to have numerous mature oocytes available for oviposition when host nests are found. Five ovarioles is an unusually large number of ovarioles for nonsocial vespoid wasps, which according to Iwata (1955) typically have three ovarioles per ovary.

Four females whose ovaries were studied had respectively $1,3,4$, and 4 mature oocytes (and in two cases several more nearing maturity). Thus they had on average 0.3 mature oocytes per ovariole, a figure that is low compared with most cleptoparasitic bees (Rozen, 2003: table 1). Of course, if a female deposits more than one egg on a single visitation to a host cell as reported by Torchio (1972a) for S. pumila, this could account for their having comparatively few mature oocytes if the $S$. luteomaculata female had just deposited eggs in a cell before she was collected. We have no certain information concerning the number of eggs a female Sapyga luteomaculata deposits on a single visit, but the relatively large number of dead first instars recovered from single cells containing overwintering Sapyga larvae in September 2006 suggests multiple-egg depositions. Multiple depositions of eggs of $S$. clavicornis in single cells have also been reported (Westrich, 1989).

EClosion AND LARVAL ACTIVITY: We observed a single hatching of an egg of Sapyga luteomaculata. A first instar, partly emerged from its chorion, was attacking the egg of another Sapyga in the same cell. In doing so, it repeatedly but briefly bit along the length of the egg. When observed a day later, the attacked Sapyga egg was reduced to a flattened chorion on the provisions. Although the host egg was uninjured when seen on the first day, it was nearly flat by the following day. Presumably the contents of both eggs had been ingested by the aggressive first instar, which had obviously eclosed while the others were still eggs. This suggests: (1) embryonic development of $S$. luteomaculata is faster than that of its host, as also reported for $S$. clavicornis (Westrich, 1989), and (2) the first cleptoparasitic egg deposited in a cell has an advantage over cleptoparasitic eggs deposited later. Westrich (1989) reported a case in which an assassinated first instar of $S$. clavicornis was not eaten after being killed by another first instar, which subsequently consumed the host egg.

Our observations of several other first instars of Sapyga luteomaculata showed that they repeatedly bit into host eggs broadside while they braced the abdominal apex against the cell wall, thereby actually forcing their mandibles into the chorion. First instars are agile (figs. 2, 3) in that they actively move around on the surface of the provisions by using the extensions of posterior body segments to push against the substrate while the anterior end of the body is raised; thus, the abdominal apex functioning as a pygopod. In this fashion they aggressively attack host eggs and other Sapyga larvae, so that only one remains to consume the provisions. Later during the first stadium, the larva seems to become less active and spends more time stretched out on the surface of the provisions, presumably feeding. This suggests that, immediately after hatching, a first instar is extremely active in seeking out and killing all other cleptoparasites as well as the host egg. These activities eliminate potential competition by other S. luteomaculata, Coelioxys coturnix, and host. Afterward the first instar's primary activity is feeding on provisions. 
Because there has been considerable confusion in studies of cleptoparasitic bees as to which instar (first, second, third, or last) is hospicidal, we retrieved the chorions of eclosed first instars of Sapyga luteomaculata and examined them with both stereo- and compound microscopes to determine if there was evidence of a previous exoskeleton contained within, which would imply a previous instar. With bees, shed chorions all but disappear, and the remnants of first instar (i.e., the "skin") can often be detected among other exuviae, though usually with difficulty. Spiracles, spiracular atria, tracheae, and occasionally the linear series of minute, thornlike spicules that rupture the chorions just above the spiracular line can be found (Rozen et al., 2006, and references therein). None of this evidence was discovered in the case of Sapyga luteomaculata, and indeed observations indicate that its eclosion is very different from that of a bee. Only the front ends of the chorion were stretched open where the first instars had emerged. All but the front end of the seemingly thick, leathery chorion remained intact, with no evident severing of the chorion along the spiracular line as found in some (perhaps most) bees (Alves-dos-Santos et al., 2002; Rozen et al., 2006). The first instar of $S$. luteomaculata simply opens the anterior end of the chorion and crawls forward to emerge, leaving behind the empty chorion (see fig. 2). Such eclosions also occur in a few groups of cleptoparasitic bees that embed their eggs in cell walls (e.g., Nomadinae [Rozen, 1992], Protepeolini [Rozen et al., 1978]).

We were unable to follow development of the larval instars of Sapyga luteomaculata during the April/May 2007 study period, but we did recover two early first instars in March/ April 2008, which gave insight instar by instar into their behavior after we had a chance to study their anatomy based on larval specimens retrieved the previous year. Much of the following is a synthesis of our behavioral observations of these two specimens correlated with our previous investigation on larval anatomy. Our subsequent visit in May 2008 confirmed and augmented these observations. The two first instars were collected on March 29 and presumably had hatched shortly before then, as judged by their slender shape. They molted early on April 1, so that the first stadium was estimated to be 3.5-4 days. The second stadium, approximately 4 days in length, ended for both during the night between April 4 and 5. The third instars both molted a few hours apart to the fourth instar during the morning of April 9, a stadium probably slightly more then 4 days long.

Although we thought during our early observations that both the first and second instars of Sapyga luteomaculata can actively attack and kill the host egg, Westrich (1989) reported that only the first instar of $S$. clavicornis did so and that the second instar transformed to a provisions feeder. We realized that our first impressions might have been incorrect because on examining the second instar of $S$. luteomaculata in the laboratory, we note that its mandibles (fig. 18) are distinctly less curved than those of the first instar (fig. 17), the pygopod is substantially reduced, the deeply incised hypostomal groove (figs. 41, 42) is now shallow, and associate pores (whatever their function) have disappeared. Consequently we endeavored to resolve our understanding of the behavioral differences between the two first instars in March/April 2008. Because newly emerged second instars respond to touch very much as actively as late stage first instars, we concluded there is no sudden change in behavior. Ownership of the provisions is probably normally determined in the earlier part of the first stadium of the first cleptoparasite to hatch. It seems unlikely that any competition extends into the later part of its first stadium much less into the second stadium.

We did not encounter cells containing more than one surviving larva of Sapyga luteomaculata. However, Torchio (in lit., April 28, 2008) stated: "Rarely two 1 st instar $S$. pumila larvae survive in one cell. When that occurs, they both develop normally and produce two smaller-sized adults that emerge in tandem from the same host cell." He then wrote: "It may be important to note here the $S$. pumila never consumes fluids from the eggs or 1st instar larvae of other S. pumila individuals."

Indirect evidence also suggest that the first instar is by far the main hospicidal form, since we found remains of many assassinated first instars in cells that we opened but never discovered older instars that had been killed. 
First instars of Sapyga luteomaculata increase considerably in body size before they molt to the second stage. The appearance of the second instar is similar to that of the first when compared under a stereomicroscope since the head is still strangely shaped (though not so much so as that of the first), antennal papillae continue to be elongate, and the modifications noted with the SEM (change in the hypostomal groove, disappearance of hypostomal pores, and the restructuring of the ventral surface of the head) are not readily visible. However, immediately noticeable is the absence of head capsule pigmentation; the head of the live second instar is as pale as the body. Only the mandibular apices continue to be dark. The head capsule is broader, but the increase in width can be detected only with measurements before and after ecdysis.

Also, the changes in the mandibles noted after laboratory preparation (figs. 17, 18) are not clearly evident on live specimens. Although the total functioning of the mandibles through the first and second stadia needs further study, they are clearly attack/defense structures and, as such, are a necessity during the first part of the first stadium. However, in neither stadium is it clear that they open and close for food ingestion, and, even if they do, the opening and closing is only sporadic, of questionable effectiveness for ingestion. The early provisions are relatively liquid, and perhaps ingestion results primarily from the actions of an esophageal pump or some such mechanism. Certainly in second instars and at least some first instars, a significant amount of pollen as well as nectar is seen in their midgut through the semitransparent body wall. If our interpretation is correct, then the shift in shape of the mandible of the second instar compared with the first can be regarded (1) as a transitional step to the broadening mandibular apex of subsequent instars and (2) perhaps as a backup weapon in an unlikely encounter with a lingering competitor.

Not only first and second but also subsequent instars open and close their mandibles when teased with a probe. All instars remain on the surface of the provisions with their dorsal surface exposed to the air; they rarely bury their entire heads and anterior thoracic segments beneath the surface of the provi- sions, as do Megachile minutissima and Coelioxys coturnix. As the second instars feed, the provisions gradually fill their midgut, and a dark area develops at the posterior end of the midgut. This dark area is quite visible from the exterior (contrasting with the uniformly pale gut content of the hosts) and was also noted by Malyshev (1968) for $S$. similis, Westrich (1989) for S. clavicornis, and Torchio (1972a) for $S$. pumila. This dark meconium accounts for the nearly black early fecal pellets (fig. 6), which first appear in the fourth instar, while later fecal deposits are paler. Although second instars occasionally raise the front part of their body from the provisions, opening and closing their mandibles with head in midair, most of the time they remain motionless, stretched out on the surface of the provisions with the front end of the head buried up to their antennae in the sticky, semiliquid food (fig. 4). Increase in body length and breadth restricts their ability to move around on the provisions since their length is nearly the same as the diameter of the surface of the provisions. Their shape viewed from above becomes navicular: broadest at midbody, front and rear ends tapering, and the dorsal surface more or less flattened. The paired pleural swelling of each body segment give a scalloped lateral outline to the sides of the body (fig. 4). Thus, second instars become nearly sedentary and are disinclined to shift position on the provisions. They do, however, respond readily when teased with a probe, though they seem to lose this responsiveness before molting to the next instar.

Behavior of the third instar is similar to that of the second in that the larva tends to be nearly motionless on the provisions but does respond when teased although this response gradually becomes slower. We detected a slight movement of the head created by mandibular activity; the larva now actively bites repetitively on provisions. As the more liquid part of the provisions are ingested, larvae occasionally move their heads over the provisions presumably to select softer provisions that are easier to loosen with their mandibles. During this stadium the body tends to loose its transparency, with the anterior portion becoming more opaque white, resulting from more rapid ingestions 
of pollen and build up of internal fat tissue (fig. 5). A small dorsal mandibular tooth is now evident, the head capsule is somewhat broader as is the abdominal girth compared with that of the second instar, and the antennal papillae are shorter. The dark meconium seemingly situated previously in the midgut appears to have move to the hind gut as a well-defined, opaque yellowish mass mottled with blackish tones, somewhat more than $0.5 \mathrm{~mm}$ in diameter, housed close to the dorsal body wall (fig. 5). It occupies a large rectal pouch seen on cleared specimens, an enlargement not observed in bee larvae.

After the completion of the April/May 2007 field study, we had not determined which instar starts defecating, but defecating larvae were clearly partly grown, so we concluded that that they may have been third or fourth instars but certainly not the first or second. The March/April 2008 study clearly demonstrated that defecation commences soon after the larva becomes a fourth instar. Depending on the taxon, all bees, including cleptoparasitic ones, commence defecation either at the beginning of the last larval instar (i.e., the fifth instar) or after they have completed feeding during the final larval instar.

We observed one fourth instar that started defecating about four hours after casting its previous exuviae. Its head capsule was again wider than that of the previous instar, the antennal papillae were now much shorter, and each mandible had developed a broadened apex with three apical, acutely pointed teeth. The meconial mass had taken on a darker hue, so that the first fecal pellets were dark grayish brown, showing little of the opaque yellow though some yellow traces were visible in the hind gut through the dorsal body wall. The larva was rather inactive but continued to feed as it slowly defecated.

Fecal pellets (fig. 6, also note those associated with cocoons in fig. 11) of Sapyga luteomaculata are large, darkly colored, and ovoid, contrasting with the paler, smaller, more elongate pellets of Megachile minutissi$m a$. Many of those of $S$. luteomaculata exhibited a small, sometimes semitransparent, taillike process usually at one end, probably the remnant of the peritrophic membrane. Feces of Osmia submicans are thin, elongate (length many times longer than width) brownish pellets, mostly attached to the cell wall, the cell closure, and the inner surface of the outside cocoon envelop. The large size, shape, and coloration of the pellets of S. luteomaculata may be characteristic of all Sapyginae (Grandi, 1962; Torchio, 1972a; Westrich, 1989). Outside of cocoons, we frequently found, in addition to the large, dark fecal pellets, clusters of small, opaque white, cylindrical pellets with truncated ends stacked one against another, the nature of which we did not understand. Torchio (1972a) reported them to be excreta, possibly of Malpighian origin. One larva that we were able to rear voided these cylindrical pellets primarily after it had voided the dark fecal material while it was spinning silk. Torchio (in lit., April 28, 2008) reported: "In S. pumila and S. angustata [Cresson], the packet of white, cylindrical pellets having truncated ends are deposited after completion of defecation and about halfway through the spinning of the outer cocoon layer. These white, hard, truncated cylinders have been observed in other cocoons of other Sapyga species from both North America and Europe and may prove to be a characteristic feature in recognizing Sapyga cocoons."

Because bees have five larval instars, we thought it likely that Sapyga luteomaculata would have the same number despite Westrich's (1989) statement that Sapyga had only four. However, we were unable to convince ourselves that differences in head pigmentation and mandibular anatomy of defecating fourth instars (see Description of Last Larval Instar, below) compared with these features on larvae taken from cocoons represent different instars. We now conclude that there are a total of four larval instars because we were able to follow several fourth instars through their defecation period to the point where they started to spin cocoons. Thus, as in bees, defecation is an indication in Sapyga that it too has reached the last larval instar, but that instar is the fourth, not the fifth as in bees. From these observations, defecation starts at, or shortly after, the start of the last larval stadium and while a large quantity of the provisions has yet to be consumed.

COCOON Description: All cocoons of Sapyga luteomaculata described here were 


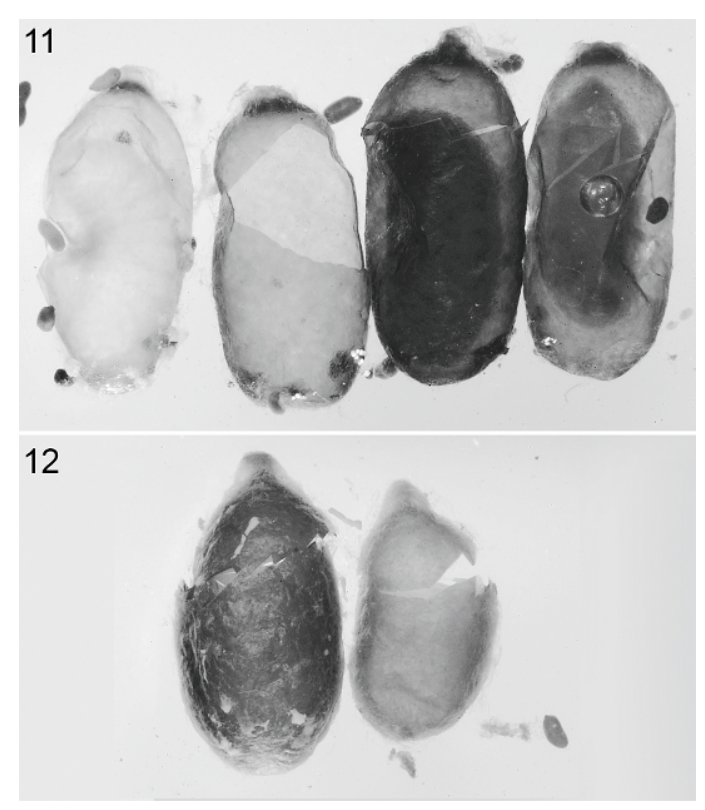

Figs. 11, 12. Macrophotographs of preserved cocoons, side view, taken from nests of Osmia submicans, all to same scale. 11. Four cocoons of Sapyga luteomaculata; left one perhaps not complete, accounting for pale coloration; second from left opened and larva removed; note fecal pellets. 12. Two cocoons of Stelis murina with larvae removed.

collected on September 19 and 20, 2006. Although they exhibited fine, pale, loose silk on the outside, their inner envelope was a denser fabric that ranged from pale, thin walled, and fragile to dark, leathery, and difficult to penetrate without scissors (fig. 11). This variability may have resulted from some cocoons being under construction when preserved, and we provisionally interpret the dark, tougher ones to be mature. Approximately $4 \mathrm{~mm} \times 8 \mathrm{~mm}$, mature cocoons consisted of dark to medium brown, semitransparent, faintly reflective fabric with an external, elongate parallel-sided ovoid shape, similar to that shown for S. pumila (Torchio, 1972a: fig. 17b) except the nipple end was slightly wider than the one illustrated. The outer surface was loosely surrounded by strands of fine silk threads that had entrapped some of the large fecal pellets of the larva. Its surface consisted of silk strands, so we assume that silk applied by the larva to construct the inner leathery surface fused to form the transparent envelope of tough, plasticlike material. The only exception was at the nipple end where the silk threads remained densely woven but not fused, presumably forming a filter enabling ventilation between the outside of the cocoon and the inside. The nipple was about $1.0 \mathrm{~mm}$ in diameter on the inner surface and $0.5 \mathrm{~mm}$ thick from the inner surface to the apex in cross section. Because all fecal material was deposited outside the cocoon, the larva must begin spinning the inner envelope after completing defecation. The cocoon seems identical in shape and size with that of Sapyga quinquepunctata Fabricius (Grandi, 1962: fig. XII), and is similar to those described for Polochrum (Hurd and Moure, 1961), though not as shiny or ovoid as that shown by Grandi (1962: fig. XXVI) and Malyshev (1931: fig. 15).

Preserved with the cocoons on September 19 and 20, 2006, were a number of cocoons of Stelis murina (fig. 12). These resembled the dark cocoons of Sapyga luteomaculata but could be easily recognized because they were slightly smaller, more opaque, perhaps thicker walled, and the nipple ends were more pointed and externally partly shrouded by fine silk. The larva within was more darkly pigmented than that of Sapyga luteomaculata, had parietal bands that were not short and pigmented, and had 10 pairs of spiracles and a long bidentate mandible with a long, slender ventral tooth, all features similar to the larva of Stelis elongativentris Parker (Rozen, 1987: figs. 6-14).

Other Cell Inhabitants: As indicated in the Introduction, Coelioxys coturnix is also a cleptoparasite of Megachile minutissima and thus is a strong competitor of Sapyga luteomaculata in nests of that host. Occasionally we encountered eggs of both in the same cell. However, we never found immatures of $C$. coturnix in nests of Osmia submicans, though we examined far fewer nests of the latter species. Because we only occasionally recovered cocoons of Stelis murina from the nests of O. submicans, it may be a low-level competitor of $S$. luteomaculata in the nests of this host species.

Because of the aggressive behavior, large size, and agility of first instars of Sapyga luteomaculata, one might suppose that they would far outcompete Coelioxys coturnix, the first instars of which are sedentary on host 
eggs, but Rozen and Kamel (2008) observed that this is not always the case.

\section{DESCRIPTIONS OF LARVAL INSTARS}

Formal descriptions of the first and last instars are presented first, followed by a description of the changes in anatomy that take place in the intermediated instars. As stated above, we conclude there are four larval instars. The following key should assist in distinguishing them.

\section{Key to Larval Instars of Sapyga luteomaculata}

1. Mandible simple, with single apical point . . 2

- Mandible with one or two teeth dorsal to longest tooth. . . . . . . . . . . 3

2. Hypostomal groove deep, with cluster of small pores behind ventral mandibular articulation; head capsule more strongly pigmented, thinner relative to length in lateral view; pygopod well developed on abdominal segment $10 \ldots \ldots$.

................ First instar

- Hypostomal groove shallow (figs. 41, 42), without pores; head capsule less pigmented, concolorous (or nearly so) with rest of body; head thicker relative to length in lateral view (fig. 41); pygopod reduced to two small lateral lobes on segment $10 . \ldots \ldots$ Second instar

3. Mandible with single tooth dorsal to ventral tooth (fig. 15); antennal papilla (fig. 43) twice as long as basal diameter; internal opaque yellowish meconial mass well defined at rear of body, close to dorsal body surface; larva not defecating. . . ...... Third instar

- Mandible with two distinct teeth dorsal to ventral tooth; antennal papilla (fig. 34) small, little longer than basal diameter; larva defecating or postdefecating..... Fourth instar

\section{Description of First Larval Instar}

Figures 13, 17, 21-30

Diagnosis: The extremely elongate antennal papilla bearing $7-8$ sensilla (figs. 22, 27) of the first instar of Sapyga luteomaculata easily distinguishes it from S. pumila, the antennal papilla of which is short and bears only three sensilla (Torchio, 1972a: fig. 30). Furthermore, the upper part of the head capsule of $S$. luteomaculata seems much more pronounced in lateral view (fig. 22) than that of
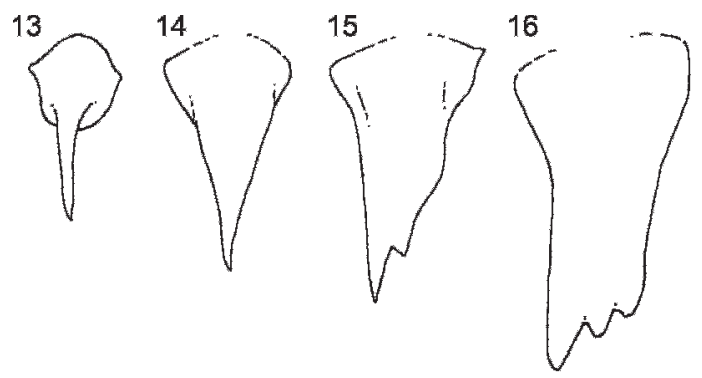

Figs. 13-16. Diagrams of right mandible with apices in maximum profile, outer views, drawn to approximately same scale; those of first three instars from cast skins attached to a fourth instar, which was not the postdefecating form. 13. First instar. 14. Second instar. 15. Third instar. 16. Fourth instar (postdefecating form).

S. pumila (Torchio, 1972a: fig. 30). Parker (1926) described and illustrated the first instar of Polochrum repandum. Like the first instar of S. luteomaculata, it is straight bodied with a head capsule darkly pigmented and more heavily sclerotized than the rest of the body and has an antenna four times as long as its basal width. Although Parker described the head in considerable detail, we are uncertain to what extent it is similar to, or different from, that of $S$. luteomaculata. He reported that it had one pair of thoracic spiracles and a pair on each of abdominal segments 1-9, which is almost certainly incorrect.

The key presented above is intended to help distinguish all of the instars of Sapyga luteomaculata. Both the first and second instars have mandibles that end in a single elongate point, whereas subsequent instars have more mandibular teeth. Its first instar can be distinguished by the characters presented in the key, but in life its relatively darkly pigmented head capsule is perhaps the most easily visible distinguishing feature. Furthermore, the mandibular apex is strongly bent as seen from above (fig. 17) or below. In contrast, the mandible of the second instar is distinctly less curved apically when viewed from above (fig. 18) or below.

DESCRIPTION: Length on hatching about $1.8 \mathrm{~mm}$, slightly less than egg length.

Head: Integument of parietals sclerotized, pigmented; mandibles strongly sclerotized and pigmented, especially apically; parietals with 


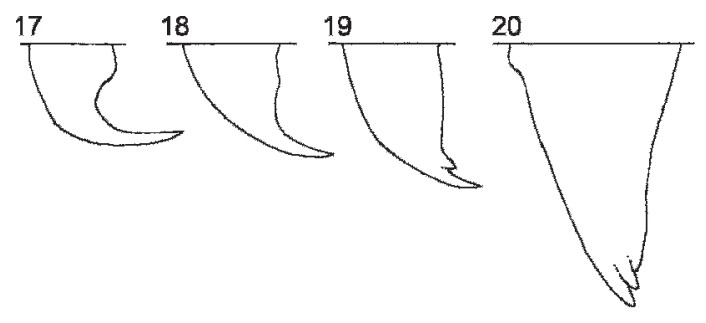

Figs. 17-20. Diagrams of right mandible, dorsal views, drawn to approximately same scale; those of first three instars from cast skins attached to a fourth instar, which was not the fourth postdefecating form. 17. First instar. 18. Second instar. 19. Third instar. 20. Fourth instar (postdefecating form).

scattered setiform sensilla and with line of sensilla extending from base of mandibles to vertex occupying position suggestive of spinulae found in Melectini (Rozen, 1969); spicules apparently completely absent from head.

Head semiprognathous (figs. 22, 23) (see Remarks below), strongly constricted behind; angle formed by hypostomal ridge relative to postoccipital ridge approximately $120^{\circ}$ as seen in lateral view; head broad and quadrate in frontal view because parietals swollen laterally; upper part of head capsule also swollen, extending upward and backward making head appear elongate and thin in lateral view (fig. 22); foramen narrow relative to head width, so that maximum width of foramen one-half maximum head width on cleared specimen; sclerotization of parietals ending posteriorly at postoccipital ridge. Tentorium moderately weakly developed, complete except lacking dorsal arms; anterior tentorial pit in deeply recessed epistomal sulcus; posterior tentorial pits in normal position but hidden by constriction behind swollen parietal; internal head ridges well defined but moderately thin (perhaps because of sclerotization of head capsule) except epistomal ridge absent between anterior tentorial pits; hypostomal ridge deeply recessed, forming deep sulcus, anterior end of which exhibits numerous pores (fig. 24) of unknown function on lower surface (discussed in Remarks, below). Parietal band absent. Antenna long, appearing to consist of two segments separated by membranous area, but cast skin demonstrating that presumed basal segment firmly attached to parietal, though with internal ring at base; true segment (papilla) long, 2.5 times longer than basal diameter, tapering, expanding slightly at apex where it bears approximately 7-8 rounded sensilla (fig. 27). Labrum broad, with large, apical, sensilla-bearing tubercle on each side (fig. 25).

Mandible (figs. 13, 17) basally stout, apically attenuate, strongly curved, ending in sharply pointed, simple apex, without tubercles or setae on outer surface; inner surface smooth, without teeth or denticles. Labiomaxillary area as seen in lateral view (fig. 22) extending little ventrally and partly eclipsed by swollen parietal above so that hypostomal ridge recessed; posterior part of labiomaxillary area completely sclerotized forming ventral, sclerotized, pigmented gular bridge between parietals posterior to membranous labiomaxillary area; this bridge firmly attached to entire length of hypostomal ridge; anterior edge of bridge arching backward in ventral view between posterior mandibular articulations; each side of bridge nearly meeting at midline, where they are apparently not fused (figs. 23, 25), being separated by a membranous median longitudinal groove. Maxilla moderately projecting apically (more so on cleared specimen than on specimen that has been critical-point dried because of shrinking and wrinkling due to critical-point drying); maxilla apically rounded, with palpus and galea not or slightly projecting, represented apically mostly by sensilla (fig. 26); stipes represented by weak, faintly pigmented sclerite on lateral part of maxilla; on SEM micrograph (fig. 26) stipes identified by broad smooth area surrounding maxillary apex except where apex is membranous and wrinkled; cardo possibly represented by small, narrow sclerite posterior to stipes, next to anterior edge of gular bridge; articulating arm of stipes not evident but transverse groove in fig. 25 may represent hypopharyngeal groove. Labium greatly recessed relative to maxillary apices, with prementum and postmentum questionably differentiated, perhaps because of gular bridge immediately posterior to labial apex (see Remarks, below, for fuller discussion of gular bridge and labiomaxillary region); labial apex bearing median slit of salivary opening and shallow diagonal fold on each side of opening; labial 

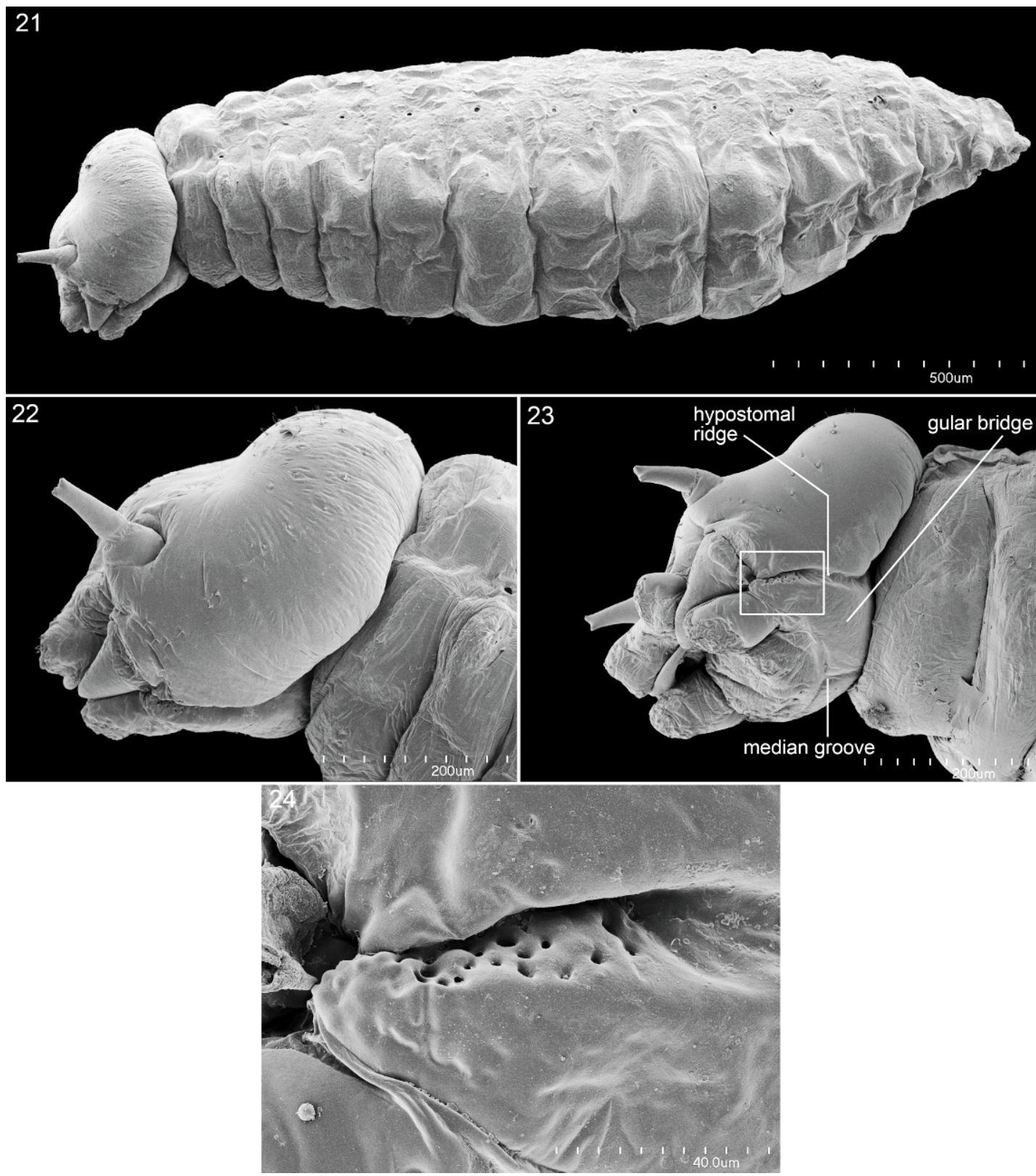

Figs. 21-24. SEM micrographs of first instar of Sapyga luteomaculata. 21. Entire larva, lateral view. 22. Head, lateral view. 23. Head, ventrolateral view, to show pronounced hypostomal groove, gular bridge, stipital sclerites. 24. Close-up of anterior part of hypostomal groove identified by rectangle in fig. 23, showing pores of unknown function.

palpus a slightly raised, sensilla-bearing area between fold at base of maxillary lobe, as seen in frontal view (fig. 25); labium completely hidden by maxilla and gular bridge in lateral view (fig. 22). Salivary opening small, trans- verse, slitlike; salivary duct evident on cleared specimen.

Body: Integument without setae; dorsal and ventral surfaces without spicules, but lateral protuberant areas on all body segments 

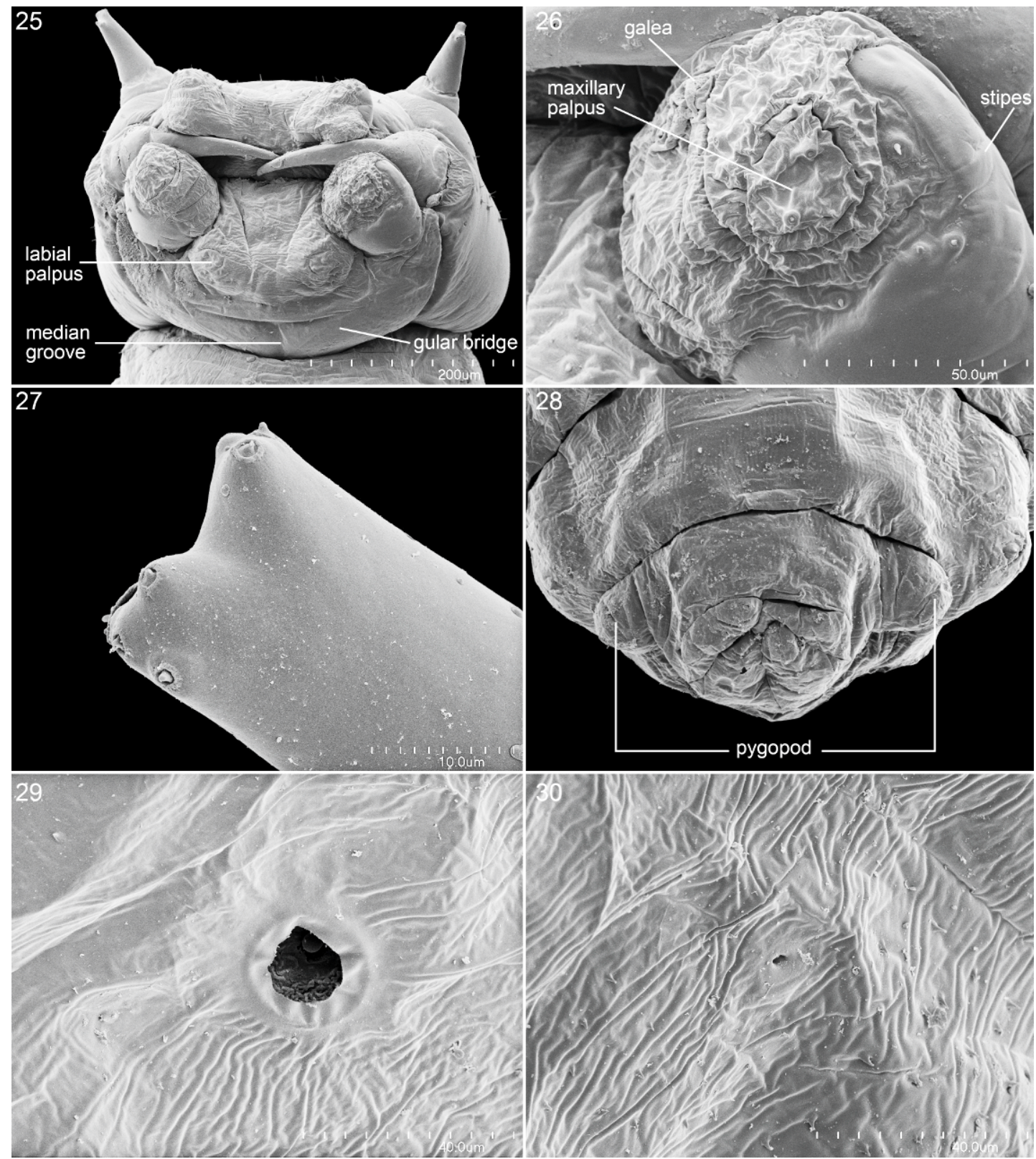

Figs. 25-30. SEM micrographs of first instar of Sapyga luteomaculata. 25. Head, approximate frontoventral view. 26. Close-up of left maxilla identifying low maxillary palpus and galea. 27. Close-up of apex of left antenna, lateral view. 28. Abdominal segment 10, showing laterally branched pygopod, caudal view. 29. Spiracle of first abdominal segment. 30. Spiracle of metathorax to same scale as fig. 29.

spiculate. Body form linear (fig. 21); intersegmental lines clearly evident but not deeply incised; body without dorsal tubercles; midbody segments each with ventral tubercle (not visible in fig. 21) that is presumably homolo- gous to that identified by Torchio, 1972a: fig. 26); these tubercles becoming obscure as larva feeds; abdominal segments not divided dorsally into cephalic and caudal annulets; prothorax and abdominal segment 9 not 
protruding ventrally; abdominal segment 10 spiculate, lateral area of each side elongate, probably somewhat eversible, used as bifurcated pygopod to assist in moving over provisions and stabilizing body against cell wall while attacking host egg or competing cleptoparasites; apex of segment 10 with pair of small, posteriorly directed, eversible lobes on each side that appear only on fully extended segment (not seen in fig. 28); anus (nonfunctional) apical between these lobes. Spiracles (fig. 29) large except for second pair of thoracic spiracles and spiracles on abdominal segment 8, which are extremely small (fig. 30), presumably nonfunctional; other spiracles uniform in size; atrium wide though atrial opening much smaller; peritreme concave on SEM micrographs, possibly due to critical-point drying; atrium without rim (fig. 29), flush with body wall, i.e., not on tubercles; subatrium without chambers.

Material Studied: Two first instars: Egypt: Tel el-Kebir, May 9, 2007 (J.G. Rozen, M. Shebl, S.M. Kamel) from nests of Osmia submicans; one first instar and one first instar skin: same except May 9, 2007; five first instars, three cast chorions, one dead ${ }^{4}$ first instar, one dead ${ }^{4}$ egg, one dead ${ }^{4}$ host egg: same except May 6, 2007 (J.G. Rozen, S.M. Kamel); two first instars: Egypt: Ismailia Experiment Station, May 7, 2007 (J.G. Rozen, S.M. Kamel).

ReMARKs: The term semiprognathous used in describing the position of the mouthparts of the first instar implies that the condition is between hypognathous and truly prognathous. The peculiar backward tilting of the head of Sapyga luteomaculata in lateral view (fig. 22) is created by the backward elongation of the head capsule and the obtuse angle formed by the hypostomal ridge relative to the postoccipital ridge in lateral view, coupled with the ventral sclerotization of the posterior part of the head, discussed below. Although the head capsule of S. pumila (Torchio, 1972a: fig. 30) seems less exaggerated than that of $S$. luteomaculata, the other features of the mouthparts of these two species seem the same (except the maxilla of $S$. luteomaculata

\footnotetext{
${ }^{4}$ That is, killed before being collected, presumably by another cleptoparasite.
}

may be less produced ventrally than that of $S$. pumila).

The ventral sclerotization of the head between the groovelike hypostomal ridges is not fully understood, but it is firmly fused laterally with the hypostomal ridges and the parietals for their entire lengths, as was observed in cast skins on which the pigmentation clearly identifies the sclerotization, which we call the gular bridge. We propose alternative explanations of the anatomy, as follows: (1) The sclerotization might be derived from the cardines, since these structures cannot be definitively identified as sclerites and the stipites can be interpreted as articulating with the ventral sclerotization. (2) Alternatively, the gular bridge may be an extension of the parietal sclerotization below and ventral to the hypostomal ridges, such that the posterior part of the labiomaxillary area, which is primarily membranous, arises from its anterior edge. The transformation of the ventral region of the head in the second instar is just as problematic (figs. 41, 42), again because of lack of sclerotization. Perhaps the median membranous groove separating the two halves of the gular bridge widens, permitting the postmentum to move posteriorly. A satisfactory explanation of the ventral sclerotization this area might be forthcoming through examination of first instars of other sapygid taxa, particularly if the specimens are larger and more fully sclerotized than is the case with this species.

An interesting feature of the first instar is the cluster of pores in the lower half of the hypostomal groove below the lower mandibular articulation (fig. 24). The fact that these pores are no longer present in the second instar and that the groove itself has all but disappeared in the second instar suggests that these two unusual features of the first instar might be functionally interrelated. Considering the way that the first instar repeatedly buries its mandibles into competitors and the host egg (fig. 3), we wonder if the groove might channel digestive fluids or venom secreted from the pores into the victim. Hypostomal grooves in first instars have been identified in a number of groups of cleptoparasitic bees including among others the Nomadinae and Melectini (Rozen, 1991). 
These taxa should be explored now with an SEM to determine whether pores exist in association with their grooves.

\section{Description OF LAST LARVA InSTAR}

$$
\text { Figures 16, 20, 32-39 }
$$

Diagnosis: The last stage larva of this species (i.e., the fourth instar) apparently shares numerous features with that of Sapyga pumila including short, pigmented parietal bands, but presumably they can be easily distinguished because the mandible of $S$. pumila has only two apical teeth (Torchio, 1972a: figs 41, 47-49) rather than three (figs. 16, 20, 35). Furthermore, the antennal papilla of $S$. pumila is shorter than its basal diameter and bears only two sensilla (Torchio, 1972a), whereas that of $S$. luteomaculata is longer than its basal diameter and bears about seven sensilla (fig. 34).

Grandi's (1962) description and illustrations indicate that the mature larva of Polochrum repandum closely resembles that of this species except the upper labral margin of $P$. repandum is angulated medially (Grandi, 1962: fig. 23) rather than evenly curved as in S. luteomaculata (fig. 32). Earlier, Parker (1926) described and illustrated the larva of the same species and remarked that the antennae were short and the mandibles had three apical teeth. However, as pointed out by Grandi (1962), Parker confused the count of the paired spiracles.

From other instars of Sapyga luteomacula$t a$, the last larval instar can be recognized by its small, nearly parallel-sided, pigmented antennal papilla. The pigmented parietal bands and the darkly pigmented maxillary and labial palpi contrasting with the white subcutaneous coloration of the rest of the head capsule will also serve well to identify the postdefecating last instar, although younger last instars are less pigmented. Other characters are presented in the accompanying key to the larval instars of this species, above.

DESCRIPTION: Length (if straight) about $6 \mathrm{~mm}$.

Head (fig. 32): Following areas moderately to darkly pigmented in postdefecating larva: parietal bands, antennal papillae, labral sclerite, mandibular articulations, maxillary scler- ites particularly near cardo-stipital articulations, articulating arms of maxillae, and all palpi. Integument with scattered, mostly setiform sensilla; spicules nearly completely absent.

Head hypognathous; imaginary angle formed by hypostomal ridge and upper part of postoccipital ridge in strict lateral view normal, close to $90^{\circ}$; vertex normally rounded above in lateral view, not swollen and extending posteriorly as in first instar; foramen moderately wide compared to head width as seen from rear, not strongly constricted behind except in vicinity of posterior tentorial pits. Tentorium robust, complete including dorsal arms; posterior tentorial pits in normal position but deeply recessed because of mesad bend of hypostomal ridge; all internal head ridges well developed except coronal ridge absent; epistomal ridge between anterior tentorial pits present but not accompanied by external sulcus, hence visible only on cleared head capsule. Parietal bands well developed, conspicuous in part because of pigmentation, shorter than distance between lower end of band and antenna. Antenna papilla (figs. 33, 34) small, almost parallel sided, slightly longer than basal diameter, arising from slight elevation, bearing about seven sensilla when viewed with SEM (fig. 34). Labrum (fig. 32) broad, with sclerite that is narrow, weakly pigmented but strongly developed, stretching across base of labrum; labral apex simply curved in frontal view (fig. 32) but appearing slightly emarginated medially when head tipped back, not bearing pair of forward projecting tubercles.

Mandible (figs. 16, 20, 35) apically broad, tridentate with ventral tooth longest and dorsal tooth shortest; teeth of feeding fourth instar appearing longer, more sharply pointed than those of postdefecating larva, perhaps because of less wear; inner surface of mandible forming shallow apical concavity; outer surface without tubercles or setae. Labiomaxillary region not strongly projecting compared with that of cocoon-spinning bee larvae, but basal part of postmentum deeply recessed into prothorax as seen on cleared head capsule; basal sclerotization of region as seen in early instars not evident; maxillary apex beyond maxillary apex bent mesad; articulating arm of 

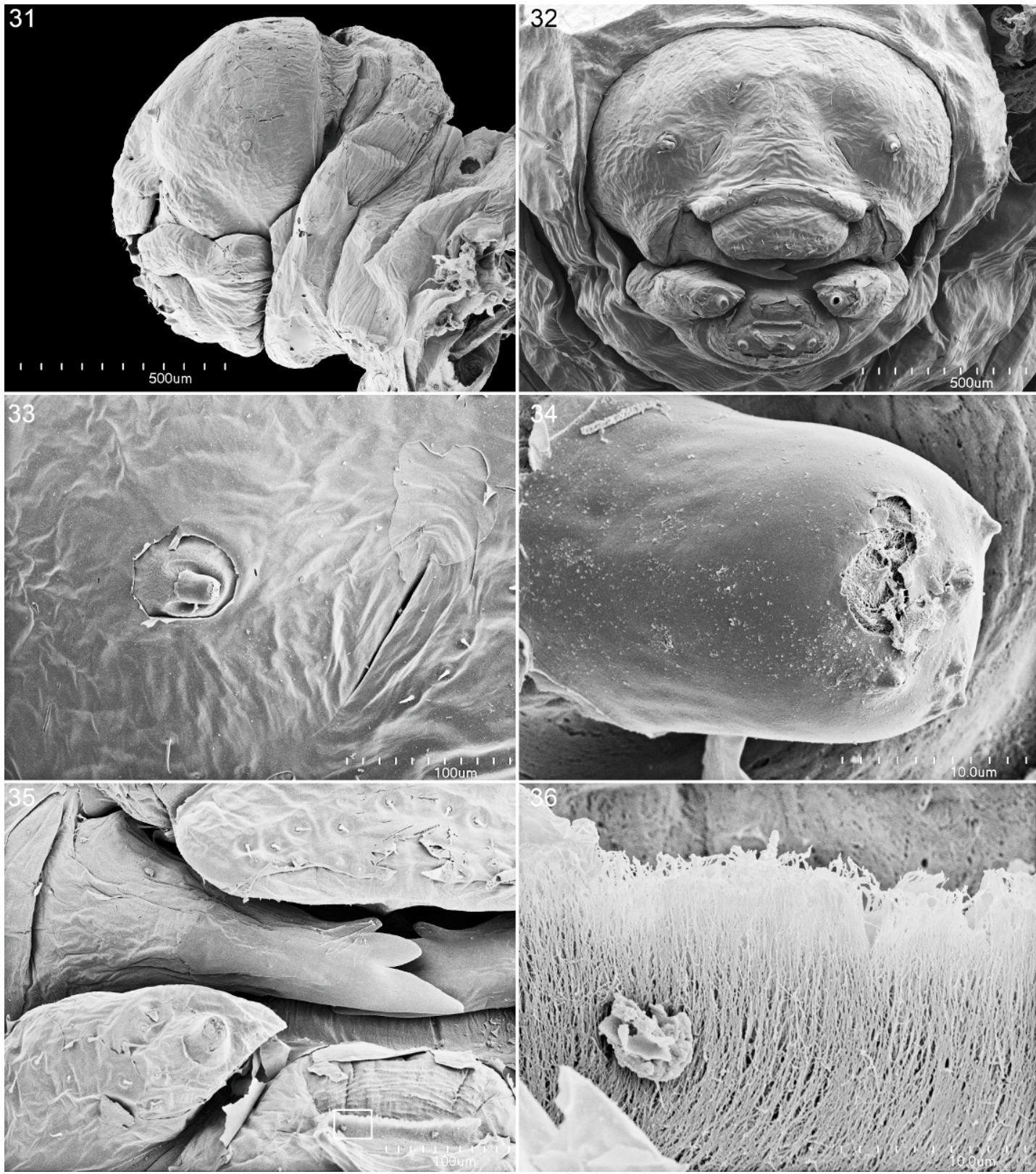

Figs. 31-36. SEM micrographs of early and postdefecating fourth instar of Sapyga luteomaculata. 31. Early fourth instar, head, lateral view. 32. Postdefecating fourth instar, head, frontal view. 33. Same, closeup of right antenna and anterior tentorial pit, frontal view. 34. Same, close-up of antennal papilla. 35. Same, right mandible showing three apical teeth, maxillary apex, and salivary opening. 36. Same, close-up of salivary opening identified by rectangle in fig. 35 .

stipes (fig. 39) a large, pigmented, thin triangle pointing mesad, appearing to be dorsal extension of premental sclerite; maxillary palpus moderately large, longer than basal diameter, all except apex darkly pigmented on postdefecating form, therefore conspicuous; galea distinct, faintly pigmented, small, less than half size of palpus. Apex of labium 

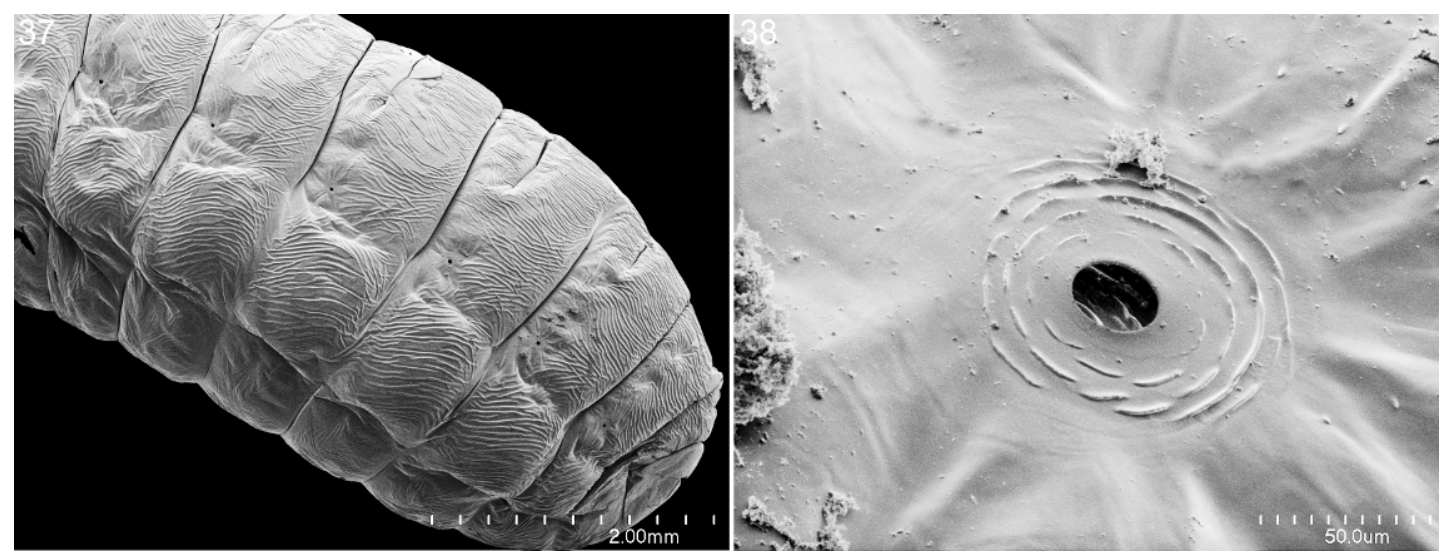

Figs. 37, 38. SEM micrographs of postdefecating fourth instar of Sapyga luteomaculata. 37. Posterior part of abdomen, lateral view, showing dorsal divisions of segments into cephalic and caudal annulets. 38. Spiracle.

moderate in width (figs. 32, 34); prementum short in lateral view; premental sclerite strongly developed but narrow, unpigmented; labial palpus pigmented except for apex, moderately large, about as long as basal diameter; labial apex below palpi in frontal view (fig. 39) with faint integumental trapezoidal pattern, at base of which there is small, apically transverse, median projection. Salivary lips broad, weakly projecting, apically microscopically fringed like a paintbrush (fig. 36).

Body (figs. 37, 40): Integument with a few widely scattered, setiform sensilla. Body without dorsolateral tubercles; each of abdominal segment 1-7 weakly divided dorsally into

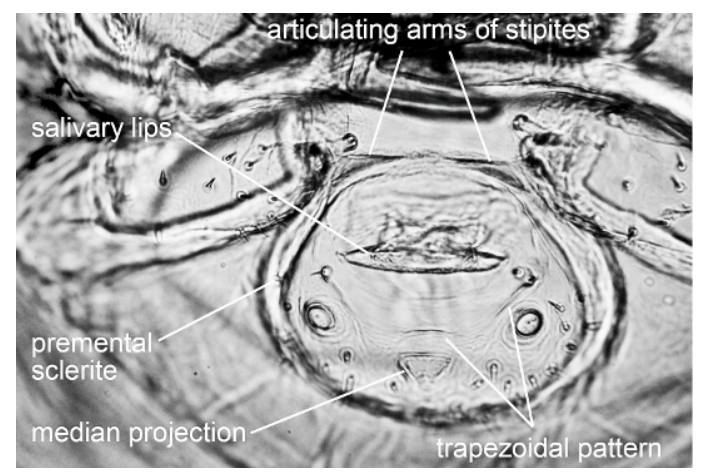

Fig. 39. Microphotograph of labium of cleared postdefecating fourth instar of Sapyga luteomaculata, showing narrow but pronounced premental sclerite, labial palpi, and articulating arms of stipites. cephalic and caudal annulets by short median fold often best observed on cleared specimen (but distinctly visible in fig. 37); cephalic annulet shorter than caudal annulet in lateral view (fig. 37); venter or abdominal segment 9 not protuberant; abdominal segment 10 attached centrally to segment 9; on larva taken from cocoon segment 10 tending to be inconspicuous, but on larva before cocoon spinning, segment 10 (fig. 40) much smaller that preceding segments but protuberant, bearing, as remnant of pygopod, pair of small tubercles above and laterad of anal slit. Pleural swellings more or less evident on abdominal segments 1-8 (fig. 37). Anus a transverse slit positioned apically on abdominal segment 10 . Spiracles nearly unpigmented; pair between pro- and mesothorax large; pair between meso- and metathorax each reduced to small, faintly pigmented spot, almost certainly nonfunctional, most easily identified by trachea leading to it on cleared specimen; abdominal spiracles on segment 18 , with pair on segment 8 often noticeably smaller than other seven pairs, which are subequal in size; atrium not projecting beyond body wall; peritreme moderately wide with raised concentric ornamentation (fig. 38); atrium globular, its wall smooth; primary tracheal opening without collar; subatrium narrow, not chambered. Sex characters unknown.

Material Examined: Ten postdefecating larvae: Egypt: Suez Canal University, Ismailia, September 19 and 20, 2006 (J.G. Rozen, 


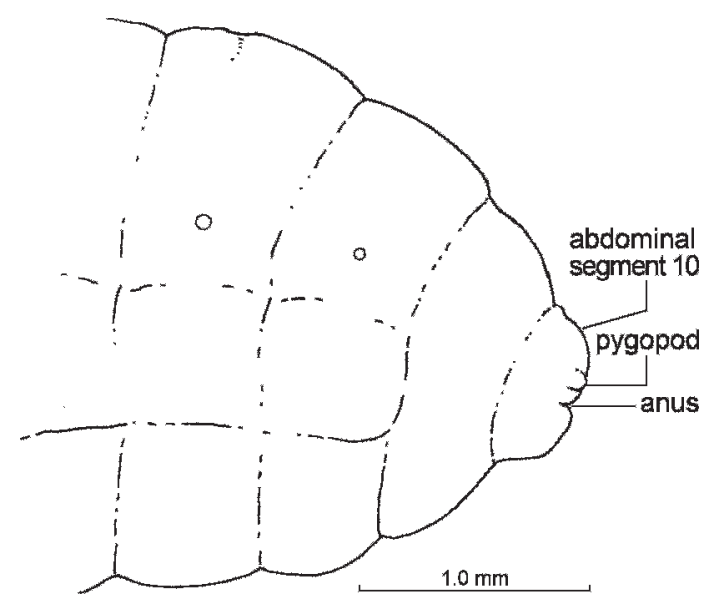

Fig. 40. Diagram of abdominal apex of mature larva of Sapyga luteomaculata before cocoon spinning, lateral view, showing small but projecting abdominal segment 10 bearing remnants of pygopod.

S.M. Kamel), from nests of Osmia submicans; one predefecating larva: Ismailia Experiment Station, May 7, 2007 (J.G. Rozen, S.M. Kamel); one fourth instar: Egypt: Suez Canal University, Ismailia, April 29, 2007 (J.G. Rozen, S.M. Kamel). Other fourth instars associated with earlier skins listed below.

\section{Discussion of Anatomical Changes between LARVAL INSTARS}

Only the first instar has a darkly pigmented head capsule, presumably suggesting that the sclerotization is thicker and stronger than in subsequent instars as has been postulated in the cases of hospicidal larvae of many cleptoparasitic bees (e.g., Rozen, 1989; Alves-dosSantos et al., 2002). Heavy sclerotization might afford the larva protection from attacking mandibles, but, because the body is unsclerotized and exposed to attack, we postulate that the extensive head sclerotization provides a firm platform for the origins of mandibular musculature. This in conjunction with enlarged parietals and the posterior constriction of the head capsule give the necessary anatomical architecture for hospicidal behavior, i.e., forceful mandibular closing.

The peculiar shape of the first instar head with its elongate, posteriorly directed vertex as seen in lateral view (fig. 22) and its laterally expanded, quadrate head shape as seen in frontal view (fig. 25) transforms gradually through a number of molts to the more familiar head shape of an aculeate larva by the early fourth instar (fig. 31), which looks nearly identical to the postdefecating fourth instar shown in frontal view (fig. 32).

The antennal papilla of the first instar (fig. 22) is greatly elongate, and it continues to be unusually long in the following two instars (figs. 41, 43), so that in the first three instars the papilla length is more than twice its basal diameter. However, in the last instar, the papilla is considerably reduced in size, with its length being only slightly greater than its basal diameter (fig. 34). The projection to which the papilla is attached, however, seems to decrease with each instar, so that by the third stage it projects little (fig. 43).

Mandibles reveal considerable modification from one instar to the next. In the first two instars the apex tapers to a single point, but in the first instar the mandible is strongly curved when seen from above or below (fig. 17), whereas in the second instar the curvature is far less (fig. 18). The third instar (fig. 15, 19) is easily recognized by the appearance of a second tooth, somewhat subapical in position, dorsal to the apical tooth. This instar lacks a distinct third tooth, which appears in the fourth instar (figs. 16, 20), but if the mandible is turned to permit a slightly dorsal view, the incipient third tooth can be detected dorsal and basal to the other two teeth. The mandible of the postdefecating fourth instar is similar to that of the defecating form but differs in that the mandible of the postdefecating form seems broader subapically and its three teeth are not as elongate or sharply pointed as those of the younger form. These differences are difficult to evaluate and partly accounted for our initial uncertainty concerning the number of larval instars. However, rearing several specimens through their fourth stadium to the start of cocoon spinning clarified the situation. Furthermore, both early and late forms of the fourth instar have projecting salivary lips (though weakly so), generally considered a hallmark of last larval instars.

Body shape on hatching is linear, and the head, because of its posterior constriction, is distinctly set off from the rest of body. 


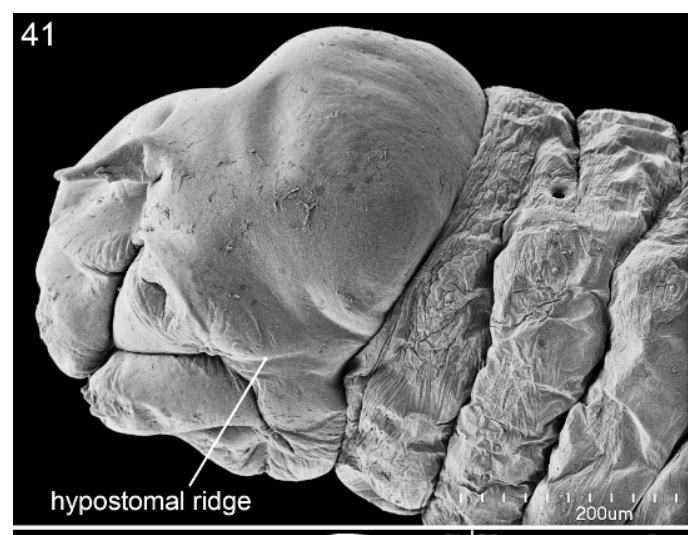

rior rim of the head. Subsequent instars increase in size and become slightly curled, and the last instar before cocoon spinning has all but the anterior surfaces of its head capsule surrounded by the prothorax.

Changes in spiracles from one instar to the next need further study to verify our observations. The first instar (figs. 21, 29) possesses a pair of large spiracles between the pro- and mesothorax and abdominal segments 1-7, which are about equal in size. The spiracles of the metathorax (fig. 30) and abdominal segment 8 are minute, coequal in size, and presumably nonfunctional. Because the metathoracic spiracles are minute in the last instar, we think this pair of spiracles is minute in all larval instars. However, the spiracles of abdominal segment 8 are nearly as large as, or somewhat smaller than, those of the preceding segment, suggesting some variability from one individual to another in the last larval instar. On two second instars, spiracular atria of abdominal segment 8 were about half the diameter of those on segment 7 , suggesting perhaps that spiracles of segment 8 increase in size incrementally from the first to the third instars.

Interestingly, the pygopod (or the remnants thereof) persists through all larval stages although it becomes obscured in larvae encased in the cocoons because of the compression of rear part of the abdomen caused by cocoon confinement.

Material Examined in Addition to First AND LAST INSTAR: One fourth instar with skins of instars 1-3 attached: Egypt: Ismailia Experiment Station, May 7, 2007 (J.G. Rozen, S.M. Kamel); one third instar skin: same; one second and one third instar: same except Tel el-Kebir, May 9, 2007 (J.G. Rozen, M. Shebl, S.M. Kamel), from nest of Osmia submicans; one fourth instar with skin of third attached: same except collected April 30, preserved May 10, 2007. Additional material from the 2008 visits also casually examined.

\section{DISCUSSION \\ DISCUSSION}

However, the body swells even during the first stadium because of food ingestion and assimilation, so that in the second instar the posterior part of the head recedes into the body, obscuring the constriction of the posteof Sapyga luteomaculata. 41. Second instar head, lateral view with hypostomal groove no longer deep or with pores. 42. Head of same, ventrolateral view. 43. Right antennal papilla and slitlike anterior tentorial pit of third instar, oblique frontal view.

Although Sapygidae are not closely related to the Apoidea, larval anatomical and behavior adaptations to cleptoparasitism reported here for Sapyga luteomaculata have anatom- 
ical and behavioral counterparts among various cleptoparasitic bees. No matter what the taxon, a cleptoparasite of a bee must: (1) find and enter the host bee's nest, (2) deposit an egg into the nest cell in such a way that it is not discovered by the host female, (3) eliminate the offspring of the host either through the action of the adult cleptoparasite or through the action of the larval cleptoparasite, and (4) be able to challenge other nest parasites. Among the many lineages of cleptoparasitic bees, various pathways have evolved that accomplish these ends. Numerous similarities in behavior and larval anatomy have evolved independently in Sapyga and in cleptoparasitic bees in response to the demands of becoming cleptoparasitic. Indeed, there seem to be few (or perhaps no) adaptations to cleptoparasitism in S. luteomaculata that are not found in one or another groups of cleptoparasitic bees. Elongate antennal papillae are uncommon among cleptoparasitic bees, but they do occur in some Dioxys (Rozen, 1967), although on the second instar, not the first (Rozen and Özbek, 2004). Modified, heavily sclerotized head capsules occur in many first instar Nomadinae (Rozen, 2003), and the ability of hospicidal forms to move around the host cells is a common phenomenon of most cleptoparasitic bees. Elongation of the ventral part of the head is also found in many cleptoparasitic taxa in the Apidae (e.g., Rozen, 2003) and Megachilidae (e.g., Baker, 1971) although in the case of $S$. luteomaculata, we are uncertain of the anatomy of the components involved. Of all the anatomical features that we see in larval $S$. luteomaculata, only the deep hypostomal groove with its cluster of minute pores at the anterior end might be uniquely involved with host killing, but even that is uncertain. Our suspicion (but convincingly reported for $S$. pumila by Torchio, 1972a) that Sapyga females may deposit more than a single egg when visiting a host cell may be a unique behavioral feature distinguishing Sapyga from cleptoparasitic bees, although Linsley and MacSwain (1955) believed that they found evidence of it in a study of a species of Nomada.

We also note that while most of the hospicidal anatomical adaptations documented for
Sapyga luteomaculata have counterparts among various groups of cleptoparasitic bees, we know of no cleptoparasitic bee taxon that has by itself the same combination of hospicidal features as $S$. luteomaculata.

\section{ACKNOWLEDGMENTS}

J.G.R. extends his appreciation to Robert G. Goelet, Chairman Emeritus, Board of Trustees, American Museum of Natural History, for his ongoing support of field investigation on bees and their parasites in many geographic centers of bee diversity in the world. He also thanks S.M.K. and President Farouk Abdel Kader of Suez Canal University for their hospitality and the courtesies extended to him during the field study. We both wish to express our appreciation to Kariman Mahmoud and Mohamed Shebl for their assistance while we were working in Egypt.

We acknowledge our appreciation to the Head of the Forage Department, Agricultural Research Center, Ismailia, for accommodating nest panels from which we took specimens at the Ismailia Experimental Station.

We thank Phil Torchio both for his review of the manuscript and for sharing his knowledge (in lit., April 28, 2008) gained from his research on other species of Sapyga. We also express our appreciation to James Carpenter and to two anonymous reviewers for their review and comments on the manuscript.

We thank Michael S. Engel for the identification of Sapyga luteomaculata. Max Schwarz and John S. Ascher kindly confirmed identifications of adult bees associated with this study.

Steve Thurston, Senior Scientific Assistant, American Museum of Natural History (A.M.N.H.), prepared the macrophotographs and illustrations for publication, and Christine LeBeau, Scientific Assistant, A.M.N.H., took the SEM micrographs of the immature stages in the Microscopy and Imaging Facility, A.M.N.H. (Emily Griffith and Rebecca Rudolph, Laboratory Managers). Translation services were kindly provided by Susanne RabGreen, Division of Invertebrate Zoology, A.M.N.H., and by Eileen Westwig, Scientific Assistant, Division of Vertebrate Zoology, A.M.N.H. Paul Nascimbene, Bee Databasing 
Project, Division of Invertebrate Zoology, A.M.N.H., copyedited the first draft.

\section{REFERENCES}

Alexander, B.A. 1996. Comparative morphology of the female reproductive system of nomadine bees (Hymenoptera: Apidae: Nomadinae). Memoirs of the Entomologcial Society of Washington 17: 14-35.

Alves-dos-Santos, I., G.A.R. Melo, and J.G. Rozen, Jr. 2002. Biology and immature stages of the bee tribe Tetrapediini (Hymenoptera: Apidae). American Museum Novitates 3377: $1-45$.

Baker, J.R. 1971. Development and sexual dimorphism of larvae of the bee genus Coelioxys. Journal of the Kansas Entomological Society 44: 225-235.

Brechtel, F. 1986. Die Stechimmenfauna des Bienwaldes und seiner Randbereiche (Südpfalz) unter besonderer Berücksichtigung der Ökologie kunstnestbewohnender Arten. Pollichia (9): 282.

Grandi, G. 1962. Contributi alla conoscenza degli imenotteri Aculeati XXXI. Bullettino dell' Isituto di Entomolgia della Università di Bologna 26: 55-102.

Hurd, P.D., Jr., and J.S. Moure. 1961. Some notes on sapygid parasitism in the nests of carpenter bees belonging to the genus Xylocopa Latreille (Hymenoptera: Aculeata). Journal of the Kansas Entomological Society 34: 19-22.

Iwata, K. 1955. The comparative anatomy of the ovary in Hymenoptera. Part I. Aculeata. Mushi 29: $17-34$.

Iwata, K. 1965. The comparative anatomy of the ovary in Hymenoptera (records on 64 species of Aculeata in Thailand with descriptions of ovarian eggs). Mushi 38: 101-111.

Iwata, K., and S.F. Sakagami. 1966. Gigantism and dwarfism in bee eggs in relation to the mode of life, with notes on the number of ovarioles. Japanese Journal of Ecology 16: 4-16.

Kojima, J. 1998. Larvae of social wasps (Insecta: Hymenoptera: Vespidae). Natural History Bulletin of Ibarakai University 2: 7-227.

Krombein, K.V., P.D. Hurd, Jr., D.R. Smith, and B.D. Burks. 1979. Catalog of Hymenoptera in America North of Mexico. Vol. 1-3. Washington. D.C.: Smithsonian Institution Press.

Linsley, E.G., and J.W. MacSwain. 1955. The habits of Nomada opacella Timberlake with notes on other species (Hymenoptera: Anthophoridae). Wasmann Journal of Biology 13: 253-276.
Malyshev, S.I. 1931. Lebensgeschichte der Holzbienen, Xylocopa Latr. (Apoidea). Zeitschrift für Morphologie und Ökologie der Tiere 23: 754-809.

Malyshev, S.I. 1968. Genesis of the Hymenoptera and the phases of their evolution. [translated from Russian, 1966]. London: Methuen.

Parker, H. 1926. Note sulla larva del Polochrum repandum Spinola (Hym. Sapygidae) parassita della Xylocopa violacea L. Bollettino del Laboratorio di Zoologia Generale e Agraria della R. Scuola Superiore d'Agricoltura in Portici 18: 268-270 (1924).

Rozen, J.G., Jr. 1967. The immature instars of the cleptoparasitic genus Dioxys (Hymenoptera: Megachilidae). Journal of the New York Entomological Society 75: 236-248.

Rozen, J.G., Jr. 1969. The larvae of the Anthophoridae (Hymenoptera, Apoidea). Part 3. The Melectini, Ericrocini, and Rhathymini. American Museum Novitates 2382: 1-24.

Rozen, J.G., Jr. 1987. Nesting biology of the bee Ashmeadiella holtii and its cleptoparasite, a new species of Stelis (Apoidea: Megachilidae). American Museum Novitates 2900: 1-10.

Rozen, J.G., Jr. 1989. Morphology and systematic significance of first instars of the cleptoparasitic bee tribe Epeolini (Anthophoridae: Nomadinae). American Museum Novitates 2957: 1-19.

Rozen, J.G., Jr. 1991. Evolution of cleptoparasitism in anthophorid bees as revealed by their mode of parasitism and first instars (Hymenoptera: Apoidea). American Museum Novitates 3029: $1-36$.

Rozen, J.G., Jr. 1992. Biology of the bee Ancylandrena larreae (Andrenidae: Andreninae) and its cleptoparasite Hexepeolus rhodogyne (Anthophoridae: Nomadinae) with a review of egg deposition in the Nomadinae (Hymenoptera: Apoidea). American Museum Novitates 3038: 1-15.

Rozen, J.G., Jr. 2001. Taxonomic key to mature larvae of cleptoparasitic bees (Apoidea). American Museum Novitates 3309: 1-27.

Rozen, J.G., Jr. 2003. Eggs, ovariole numbers, and modes of parasitism of cleptoparasitic bees, with emphasis on Neotropical species (Hymenoptera: Apoidea). American Museum Novitates 3413: 1-36.

Rozen, J.G., Jr., K.R. Eickwort, and G.C. Eickwort. 1978. The bionomics and immature stages of the cleptoparasitic bee genus Protepeolus (Anthophoridae, Nomadinae). American Museum Novitates 2640: 1-24.

Rozen, J.G., Jr., and S.M. Kamel. 2007. Investigations on the biologies and immature stages of the cleptoparasitic bee genera Rados- 
zkowskiana and Coelioxys and their hosts in the genus Megachile (Hymenoptera: Apoidea: Megachilidae: Megachilini) American Museum Novitates 3573: 1-43.

Rozen, J.G., Jr., and S.M. Kamel. 2008. Hospicidal behavior of the cleptoparasitic bee Coelioxys (Allocoelioxys) coturnix, including descriptions of its larval instars (Hymenoptera: Megachilidae). American Museum Novitates 3636: $1-15$.

Rozen, J.G., Jr., G.A.R. Melo, A.J.C. Aguiar, and I. Alves-dos-Santos. 2006. Nesting biologies and immature stages of the tapinotaspidine bee genera Monoeca and Lanthanomelissa and of their osirine cleptoparasites Protosiris and Parepeolus (Hymenoptera: Apidae). American Museum Novitates 3501: 1-60.

Rozen, J.G., Jr., and H. Özbek. 2004. Immature stages of the cleptoparasitic bee Dioxys cincta
(Apoidea: Megachilidae: Megachilinae: Dioxyini). American Museum Novitates 3443: 1-12.

Torchio, P.F. 1972a. Sapyga pumila Cresson, a parasite of Megachile rotundata (F.) (Hymenoptera: Sapygidae: Megachilidae). I: Biology and description of immature stages. Melanderia 10: 1-22.

Torchio, P.F. 1972b. Sapyga pumila Cresson, a parasite of Megachile rotundata (F.) (Hymenoptera: Sapygidae: Megachilidae). II. Methods for control. Melanderia 10: 23-30.

Torchio, P.F. 1979. An eight-year field study involving control of Sapygda pumila Cresson (Hymenoptera: Sapygide), a wasp parasite of the alfalfa leafcutter bee, Megachile pacifica Panzer. Journal of the Kansas Entomological Society 52: 412-419.

Westrich, P. 1989. Die Wildbienen Baden-Württembergs Allgemeiner Teil: 1-431. Stuttgart: Eugene Ulmer.

Complete lists of all issues of the Novitates and the Bulletin are available at World Wide Web site http://library.amnh.org/pubs. Inquire about ordering printed copies via e-mail from scipubs@amnh.org or via standard mail from: American Museum of Natural History, Library-Scientific Publications, Central Park West at 79th St., New York, NY 10024. TEL: (212) 769-5545. FAX: (212) 769-5009. 